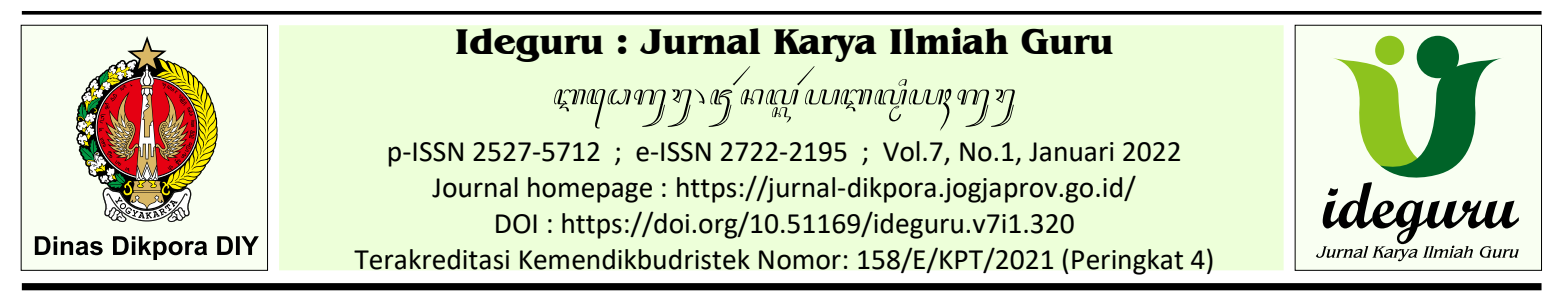

Artikel Penelitian - Naskah dikirim: 11/11/2021 - Selesai revisi: 23/12/2021 - Disetujui: 28/12/2021 - Diterbitkan: 01/01/2022

\title{
Pemaknaan Motif Hias Sarung Tenun Sutera Mandar dalam Pembinaan Karakter Siswa
}

\author{
Amri \\ SMA Negeri 1 Polewali, Polewali Mandar, Sulawesi Barat, Indonesia \\ Artamri119@gmail.com
}

\begin{abstract}
Abstrak: Penelitian ini bertujuan untuk memahami dan menggali informasi pemaknaan motif hias sarung tenun sutera Mandar sebagai kearifan lokal di Polewali Mandar. Nilai-nilai pendidikan karakter apa yang terkandung pada ragam hias sarung tenun sutera Mandar. Internalisasi makna ragam hias terhadap nilai-nilai pendidikan karakter bagi peserta didik di sekolah. Penelitian ini menggunakan metode penelitian deskriptif kualitatif melalui pendekatan antropologi. Pengumpulan data dilakukan melalui studi pustaka, wawancara dan observasi langsung. Objek penelitiannya adalah ragam hias sarung tenunan sutera mandar dan siswa SMA Negeri 1 Polewali. Hasil penelitian menunjukkan; 1. Ragam hias sarung tenun sutera Mandar sebagai kearifan budaya lokalnya berbentuk pola segi empat. Memiliki makna yang esensial dalam masyarakatnya meliputi berkaitan dengan simbol isi alam semesta dan nilai-nilai luhur sifat manusia yaitu kejujuran, keadilan berkata benar dan keteguhan pendirian. 2. Nilai-nilai pendidikan karakter yang ada pada ragam hias sarung tenun sutera Mandar sebagai nilai luhur sifat manusia dapat ditransfer dalam pembinaan karakter siswa diantaranya nilai religus, kejujuran, kemandirian, kerjakeras, kreatif, dan kerjasama. 3. Internalisasi pemaknaan ragam hias sarung tenun sutera Mandar terhadap nilai-nilai karakter bagi peserta didik dapat terwujud dengan perubahan sikap, perilaku, dan penampilan siswa dalam berinteraksi di sekolah.
\end{abstract}

Kata kunci: ragam hias tenun; sutera Mandar; karakter siswa.

\section{Meaning of the Decorative Patterns on Woven Silk Mandar Sarongs in Character Building Students}

\begin{abstract}
This study aims to understand and explore the meaning of the decorative motif of the Mandar silk woven sarong as local wisdom in Polewali Mandar. The value of character education value is contained in the ornamental variety of Mandar silk woven sheaths. Internalization of the meaning of ornamental variety to the values of character education for learners in school. This study uses a qualitative descriptive research method through an anthropological approach. Data collection is done through library studies, interview, and direct observation. The object of his research is a variety of ornamental Mandar silk woven sheaths and students of SMA Negeri 1 Polewali. The results showed; 1 . The ornamental variety of Mandar silk woven sheaths as the wisdom of local culture is in the form of a rectangular pattern. Having an essential meaning in its society includes relating to the symbol of the content of the universe and the noble values of human nature, namely honesty, justice and firmness of the establishment. 2. The value of character education values that exist in the ornamental variety of Mandar silk woven sheaths as the noble value of human nature can be transferred in the formation of student character including religious values, honesty, independence, hard work, creative, and cooperation. 3. Internalization of the meaning of ornamental varieties of silk weaving sarongs to the value of character values for learners can be realized by changes in attitudes, behavior, and appearance of students in interacting in school.
\end{abstract}

Keywords: weaving decorations; Mandar silk; student characters.

\section{Pendahuluan}

Tenunan merupakan salah satu bagian dari kebudayaan etnis nusantara tumbuh dalam poroses pemikiran dan penyesuaian, perkembangan hidup dari suatu suku bangsa yang berkaitan dengan lingkungan alam, sosial serta sistem kepercayaan. Potensi tenunan yang terdapat dari berbagai etnis nusantara tentunya terkait dengan kondisi sumber daya alamnya. Hasil tenunan mencerminkan ikon, ciri khas, dan identitas bagi masyarakat komunitas daerah tersebut.

Seni kerajinan tenun telah lama tumbuh dalam kebudayaan nusantara, tinggi mutu estetisnya, dapat mengidentifikasikan kekhasan nusantara dan mewujudkan rasa kebanggaan 
tersendiri untuk dikembangkan serta mempertinggi mutunya pada perkembangan kebudayaan nasional (Koentjaraningrat, 1983: 116-117).

Aktivitas menenun disetiap suku bangsa pada dasarnya terdapat ciri khas dari setiap etnis, terutama pada bentuk pola ragam hiasnya yang melahirkan motif tersendiri. Bentuk ragam hias tenunan tersebut diantaranya motif geometris, non geometris, motif stilasi tumbuhan dan hewan serta motif manusia. Keberadaan ragam hias dalam tenunan selain berfungsi sebagai hiasan juga mengandung arti simbolik dan nilai nilai luhur budaya bagi masyarakat komunitasnya. Hal ini dipertegas oleh Kartiwa dengan pernyataan bahwa ragam hias dalam tenunan memiliki makna dan fungsi dalam kehidupan manusia yang bersumber pada falsafah hidup dalam tujuan penciptaannya.

Perbedaan aktivitas masyarakat yang berbeda-beda dipengaruhi oleh nilai budaya dan adat istiadat yang dilahirkan oleh leluhurnya. Filosofi kehidupan tergambarkan dan nampak jelas dalam adat istiadat, serta terkait dengan kepercayaan dan agama yang diyakininya. (Kartiwa, 2007: 10) Pendapat tersebut memberikan pemahaman bahwa keberadaan pola ragam hias pada kain tenunan merupakan suatu ungkapan pernyataan rasa kreasi, dan tergambarkan arti yang mendalam tentang keberadaannya bagi masyarakat pendukungnya.

Masyarakat di Kabupaten Polewali Mandar memiliki karya kerajinan tenunan yang diwariskan dari leluhur mereka dikenal sebagai sarung tenun sutera Mandar, dan masih eksis sampai sekarang. Tenunan tersebut terdapat bentuk ragam hias, yang mengandung falsafah hidup dan nilai dalam kehidupan masyarakatnya, sebagai aset yang ternilai. Eksistensi bentuk ragam hias sarung tenun sutera Mandar selain bernilai estetis juga bermakna simbolik bagi masyarakatnya.

Dalam menelusuri budaya lokal bangsa, khususnya budaya menenun di Polewali Mandar, sikap perilaku berkarakter beradab, sopan santun dan berakhlak mulia sudah tercermin, tertata, tertanam dan terpelihara dengan baik yang dijadikan sebagai landasan kepribadian dan identitas bangsa. Perilaku tersebut teraplikasikan dan diwujudkan dalam pembuatan tenunan pada motif hias sarung tenun sutera Mandar. Hal ini sebagai dasar pijakan sikap dan perilaku moral masyarakat di Polewali Mandar dalam menata kondisi kehidupan sosial budayanya sebagai wujud kearifan lokalnya. Nilai nilai luhur tersebut yang telah lama tertata dan tertanam dimasyarakatnya serta teraplikasi dalam dirinya sebagai warisan pendahulunya.

Kondisi menghawatirkan dalam masyarakat saat ini, seiring dengan perkembangan era globalisasi. Dengan munculnya berbagai fenomena watak sikap yang menghawatirkan yaitu dengan pergeseran nilainilai moral dan kepribadian tanpa disadari telah melanda generasi bangsa. Krisis yang mengancam dan melanda adalah krisis moral, seperti tergesernya rasa saling menghormati, toleransi, peduli dan sopan santun. Bahkan perilaku remaja dengan kegemaran menduplikasi, kurang percaya diri, tidak jujur, pembentukan kelompok gen yang arah dan tujuannya tidak positif, senang menghakimi teman di sekolah dan keributan antara kelompok gen. Kenakalan lainnya pada kasus miras dan narkoba. Menurut Muchlis data menunjukkan bahwa dari 4 jutaan pecandu narkoba, adalah anak usia sekolah, yang berusia remaja. (Muchlis, 2016: 57)

Kehidupan masyarakat di era modernisasi dan globalisasi telah merubah model yang berbeda dalam berbagai sendi kehidupan. Kenyataannya erah pembaharuan telah menyebar diberbagai perilaku dan watak dalam sendi kehidupan khususnya dikalangan remaja. Menurut Darajat, stratifikasi sosial masyarakat yang gampang terpengaruh dari budaya luar adalah remaja, karena mereka sedang mengalami keguncangan emosi yang labil karena dinamika pertumbuhan dan perkembangannya. (Zakia Darajat, 2009: 94). Dampak negatif dari pengaruh globalisasi yang menghawatirkan pada sendi kehidupan pendidikan dengan sering terjadinya penyimpangan dan lunturnya nilai karakter baik dikalangan remaja. Sebagaimana dalam urain di atas sebagai dampak negatif perilaku generasi muda merupakan contoh telah bergesernya nilai-nilai pendidikan karakter atau budi pekerti.

Pergeseran nilai nilai karakter diawali dengan perubahan sikap perilaku yang kurang terpuji misalnya dengan menampakan perilaku egoisme, merasa benar dengan pendapatnya, tidak bersahabat, penghargaan kepada yang lebih tua terabaikan. Bergesernya nilai nilai karakter generasi mudah tersebut karena penanaman sifat dan keperibadian tentang nilai nilai luhur budaya sebagai kearifan lokalnya, tidak dipahaminya. Sehingga mudah untuk ditumbangkan oleh budaya luar akibat pengaruh budaya global. 
Menyikapi fenomena yang terjadi di atas maka lembaga pendidikan yang utama adalah sekolah yang merupakan bagian dari pendidikan formal, memiliki peranan penting untuk mendidik dan membentuk sumber daya manusia yang berkualitas dalam melanjutkan pembangunan bangsa. Eksistensi sekolah sebagai lembaga pendidikan dalam mencetak generasi yang unggul dan berakhlatul kharima, tentunya memiliki peran utama dalam pembinaan akhlak dan moral. Sekolah sebagai lembaga pendidikan tidak sertamerta memiliki misi dalam pentrasperan ilmu dan keterampilan namun yang paling penting adalah pembinaan afektif sebagai perwujudan sikap dan perilaku yang beradab. Peranan sekolah tentunya diupayakan untuk melaksanakan visi dan misinya yang orientasinya dalam mencerdaskan kehidupan berbangsa dan berbudi pekerti luhur. Sehingga saat ini visi dan misi pendidikan selain membekali peserta didik dalam kemampuan intelektual dan skil juga mengutamakan perwujudan pada jiwa dan kepribadian budaya bangsa yang awalnya berpegang teguh kepada nilai-nilai luhur budaya bangsa. Kecenderungan untuk kembali membenahi kehidupan yang berasaskan pada nilai- nilai luhur dan budaya lokal geniusnya. Sehingga dapat menstabilkan kesadaran kita tentang arti dan makna budaya leluhur. Gambaran pendidikan yang bermutu seharusnya didasari pada nilai-nilai lokal geniusnya, yang ditanamkan pada masyarakat komunitasnya. Dapat melahirkan pendidikan bermakna, dalam pembentukan karakter peserta didik yang bermutu. Hal ini seiring dengan program pemerintah yaitu Penguatan Pendidikan Karakter (PPK).

Wujud pendidikan karakter yaitu bagaimana dapat menanamkan karakter positif, dan perilaku luhur yang dinampakan oleh setiap manusia yang berbudi pekerti. Gambaran hal tersebut di atas terlihat dalam interaksi sosial pada manusia itu sendiri. Sikap dan kepribadian, serta tanggung jawabnya. Melihat sisi kehidupan dunia pendidikan di sekolah, maka terdapat beragam perilaku yang tidak senada dengan pengetahuan dan keterampilan dalam diri siswa. Gambaran tentang pergeseran nilai- nilai luhur bangsa sebagai wujud kearifan lokal yang diwariskan dari pendahulunya, dirasa sangat perlu dan urgensi ada tindakan yang berasaskan kembali menggali arti dan makna yang disimbolkan yang terdapat pada gambaran ragam hias sarung tenunan sutera Mandar sebagai wujud kearifan lokalnya. Sehingga dapat mewujudkan pembinaan karakter bagi peserta didik di sekolah khususnya SMA Negeri 1 Polewali Kabupaten Polewali Mandar.

Berdasarkan tinjauan konseptual nilainilai budaya pada ragam hias sarung tenun sutera Mandar tersebut, terhadap penerapan pendidikan budi pekerti (karakter) bagi siswa di SMA Negeri 1 Polewali, maka penelitian ini merumuskan masalah. Bagaimana pemaknaan ragam hias sarung tenun sutera Mandar sebagai kearifan budaya lokal di Polewali Mandar. Bagaimana nilai-nilai pendidikan karakter yang terkandung pada motif hias sarung tenun sutera Mandar. Bagaimana internalisasi makna ragam hias sarung tenun sutera Mandar terhadap nilai nilai pendidikan karakter bagi peserta didik.

Penelitian ini didukung oleh kajian teori yakni pertama batasan ragam hias dan pemaknaannya (simbolik). Ragam hias merupakan suatu bentuk karya seni rupa telah berkembang dimulai dari era primitif hingga sekarang. Indonesia yang memiliki multi etnis terdapat beragam budaya termasuk ragam hias, yang beraneka ragam corak dan motif. Keberagaman ragam hias tersebut didukung oleh faktor lingkungan alamnya baik biotik maupun abiotik, hingga kondisi sosial budayanya.

Ragam hias berperan sebagai media untuk memperindah atau mengagungkan sesuatu karya seni rupa secara lahiriah. Bahkan juga mengandung nilai simbolik atau makna tertentu. Ragam hias tidak terlepas dari unsur-unsur yang menjadi pendukung terjadinya bentuk visual tersebut yaitu garis, bidang, tekstur bahkan juga warna yang merupakan bagian yang elementer (Toekio, 2003: 2-3). Pembuatan ragam hias didasari oleh keinginan komunitasnya, baik yang berkaitan dengan fungsi pakai maupun keterkaitan unsur religius. Sehingga keberadaan ragam hias juga terdapat arti dan tanda atau lambang, yang berkaitan dengan tatanan kehidupan dalam komunitas lokal geniusnya. (www.habibullahurl.com). Pendapat tersebut memberikan suatu pemahaman bahwa simbol merupakan hasil pemahaman atau kesepakatan bersama. Mempunyai arti dan nilai secara fungsional yang sangat penting dalam kehidupan manusia.

Yudha Triguna dalam Dharsono (narasumber) lebih lanjut menjelaskan bahwa, tanda atau simbol adalah ungkapan ekspresi dua hal yaitu antara nilai dan harga. Nilai terkait dengan hal yang berdimensi sesuatu, dinyatakan berharga. Tanda atau simbol dapat diwujudkan pada sesuatu hal dengan memiliki nilai kemanfaatannya sebagai ciri khas masyarakatnya dari setiap etnis. Sehingga simbol atau tanda 
dapat berfungsi sebagai acuan atau desain dalam berperilaku dan media sosial dalam kekerabatanya pada masyarakat komunitasnya (Dharsono, 2007: 24-25). Lebih lanjut pemahaman simbol pada bentuk ragam hias sarung tenun sutera Mandar dapat dipahami secara menyeluruh bila memahami sistem budaya masyarakatnya. Seperti yang dikemukakan oleh Tjetjep Rohendi Rohidi dalam Dharsono bahwa, kebudayaan sangat terkait dengan sistem simbol, yaitu merupakan desain dan penentu pola hidup bagi masyarakatnya (Dharsono, 2007: 24). Suatu hal yang semakin membuat ragam hias bermakna bagi kebudayaan, khususnya di Polewali Mandar dengan keberadaanya sebagai tanda yang mengandung arti terpenting terhadap komunitasnya tentunya di dalamnya mempunyai identitas sebagai cirikhas dan acuan atau pedoman dalam merajut kehidupan sosialnya.

Kajian teori yang kedua antara lain menurut Kasiyan (2007: 6) Budaya lokal diartikan sebagai kebiasaan atau tradisi yang dianut dalam suatu masyarakat dan timbul secara terpadu dan mempunyai keterkaitan antara pola pikir dalam kehidupan sosialnya. Sehingga dapat mewujudkan kekhasan tersendiri dalam beraktivitas secara lestari serta dijunjung tinggi oleh masyarakatnya.

Pemahaman terhadap budaya lokal atau lokal genusnya merupakan bentuk dari nilai-nilai kedaerahan tertentu yang berbedah dengan daerah lainnya. Nilai nilai kedaerahan tersebut biasanya terbentuk secara lamia seiring dengan perjalan ruang dan waktu. Biasanya tergambarkan jenis karya seni pertunjukan dan seni rupa tradisional, aturan, hukum adat, kepercayaan, serata pola pemikiran yang dianggap berharga. Hal ini menyebabkan keberagaman budaya lokal yang dimiliki oleh masyarakat Indonesia karena memiliki wilayah yang luas dan perbedaan suku dan etnis.

Pengertian nilai dalam konsep budaya lokal dijelaskan oleh Faisal, bahwa kata nilai digunakan untuk merujuk pada makna simbol yang diatur menurut pola kebiasaan tertentu. Mutu pada simbol tertentu dapat dijadikan penentu nilai karakter yang berkaitan pada aspek kebiasaan yang bersifat lokal yang dikaitkan dengan aspek budaya yang bersifat kaidah yang berlaku. Sehingga sesuatu yang berharga merupakan suatu ide konsep yang disepakati manusia dalam mewujudkan karakter pada masyarakat atau komunitasnya (Faisal, 2008: 121). Nilai budaya pada masyarakat tertentu merupakan ide gagasan yang hidup dalam alam pikiran dari warga komunitasnya, tentang halhal yang mereka anggap sangat berarti pada kehidupannya sebagai warga masyarakat (Koentjaraningrat, 1983: 25).

Falsafah hidup merupakan sikap batin yang paling mendasar yang dimiliki masyarakat sebagai upaya berfilsafat dalam mewujdkan kebijaksanaan. Falsafah hidup secara mendasar, dapat dipahami sebagai nilai nilai budaya sosial bagi masyarakat lokal genusnya digunakan untuk pedoman beraktivitas keseharian. Nilai normatif tersebut masih dipegan teguh pada masyarakat di Polewali Mandar yang implementasinya dijadikan roh atau spirit dalam menetapkan pola gagasan dan menjadikan hal yang dilakukan dalam masyarakat.

Mengacu dengan pola hidup secara tradisional bagi komunitas budaya masyarakat di Mandar nilai nilai budaya luhur dijadikan sebagai pedoman, semangat dan disiplin kerja, perilaku yang dilatarbelakangi oleh budaya tradisi atau adat istiadat (pengaderan) sebagai falsafah hidup. Kaitanya dengan falsafah hidup menurut Anwar Sewang menuturkan sebagai berikut. Menjaga adat istiadat itu adalah hak yang mutlak atau hal yang sangat esensial dalam kehidupan dan sangat penting dengan didasari oleh rasa malu yang dilandasi oleh kekuatan budaya malu (Sewang Anwar, 2015: 7).

Masyarakat di daerah Polewali Mandar mempunyai kebiasaan adat tradisi yang terpola dan terorganisir yang tertata sedemikian rupa sebagai warisan leluhur mereka yang tindakan kesaharianya dijadikan sebagai tatanan dalam mengatur pola interaksi sosial kulturnya. Sebagai falsafah hidup yang didasari dengan adat istiadat dan sumber ajaran agama Islam yang diyakininya. Hal ini menampakan realita kehidupannya yang harmonis dan bijaksana aman dan damai. Hubungannya pada pola ragam hias tenunan sarung sutera Mandar sebagai unsur hasil karya cipta dan karsa manusia yang dikenal sebagai wujud kebudayaan tentunya terkait dengan arti dan gambaran karakter sikap dan perilaku masyarakat komunitasnya yang digunakan sebagai acuan secara kolektif dalam beraktivitas, bernalar yang telah disepakati bersama (Guntur, 2008: 55). Maka eksistensi ragam hias tentunya merupakan hasil ekspresi budaya bagi masyarakatnya yang memiliki fungsi diantaranya sebagai nilai, aturan, tatakrama dan falsafah hidup bagi masyarakatnya.

Hakikat pendidikan karakter merupakan amanat konstitusional yang berasaskan pada Pancasila dan tujuan negara yang dituangkan dalam pembukaan UUD 1945. Dalam mewujudkan insan manusia yang beriman dan 
bertaqwa dalam mencetak manusia seutuhnya. Namun kenyataannya masih adanya problema kebangsaan terjadi saat ini, diantaranya, radikalisme, perbedaan pandangan serta belum sepenuhnya penghayatan pengamalan nilainilai Pancasila, pergeseran nilai-nilai moral dan karakter dalam kehidupan berbangsa dan bernegara. (Kementerian Pendidikan Nasional 2011). Pendidikan karakter identik sebagai pembinaan mental spritual yang berbudi pekerti plus, yang senantiasa mengakomodir pada ranah kognitif, feeling dan action. Lebih lanjut dikemukakan oleh Jamal Ma'mur Asmani (2011: 31) Pendidikan karakter sebagai upaya dan tindakan yang dilakukan oleh pendidik untuk membentuk watak kepribadian baik peserta didik dengan cara mecontohkan keteladanan yang baik diantaranya hormat menghormati, toleransi, berkata jujur peduli sesama dan sikap religius.

Perwujudan pendidikan karakter tidak sebatas memberikan pemahaman kepada peserta didik mana yang benar dan mana yang salah, tapi hal yang urgen pendidikan karakter mendidik pembiasaan anak tentang hal yang baik yang tidak melanggar norma dan aturan serta tetap menjujung nilai nilai luhur sebagai kepribadian budaya bangsa.

Dalam kajian ini beberapa contoh nilai nilai karakter yang dirujuk dari pusat perbukaan nasional yang orientasinya mengacuh pada nilai nilai pendidikan karakter yang bersumber dari agama, Pancasila budaya dan tujuan pendidikan nasional, meliputi: (1) sikap religius, keyakinan (2) perilaku jujur (3) Toleransi saling menghargai (4) Perilaku disiplin (5) Kerja Keras, (6) Kreatif, (7) Kemandirian, (8) Demokratis (9) Rasa Ingin Tahu, (10) Semangat Kebangsaan, (11) Mencintai Tanah Air (12) Menghargai Prestasi (13) Bersahabat komunikatif, (14) Cinta Damai, (15) Gemar Mambaca, (16) Adiwiyata, (17) Kepedulian sosial (18) Tanggung Jawab (Kementerian Pendidikan Nasional, 2011: 3)

Adapun tujuan penelitian ini adalah. Untuk mengetahui pemaknaan ragam hias sarung tenun sutera Mandar sebagai kearifan budaya lokal di Polewali Mandar. Untuk mengetahui nilai-nilai pendidikan karakter apa yang terkandung pada ragam hias sarung tenun sutera Mandar. Untuk mengetahui internalisasi makna pada motif ragam hias sarung tenun sutera Mandar terhadap nilai nilai pendidikan karakter bagi peserta didik. Tulisan ini diharapkan bermanfaat di perpustakaan sebagai referensi dan menambah khasanah ilmu pengetahuan tentang nilai-nilai budaya lokal yang terdapat pada ragam hias sarung tenun sutera Mandar serta internalisasi pendidikan karakter di sekolah. Manfaat praktisnya. Bagi sekolah dapat digunakan sebagai acuan dalam pembinaan karakter bagi peserta didik di sekolah, untuk diaplikasikan dalam kehidupan sehari- hari sehingga tercipta pembentukan pendidikan karakter sebagaimana yang diharapkan.

\section{Metode Penelitian}

Metode yang digunakan dalam kajian ini adalah kualitatif deskriptif. Dilakukan dengan cara mendapatkan data informasi yang kajiannya pada kekuatan makna. Data dikumpulkan terutama pada pernyataan analisis yang sesuai dengan kenyataan di lapangan. Sumber data yang digunakan dikelompokan antara lain. Narasumber tokoh masyarakat, budayawan Mandar, peneliti budaya Mandar praktisi pendidikan, guru. Sumber tertulis buku referensi yang membahas tentang ragam hias, tenunan, teori simbol, pendidikan karakter pada peserta didik. Dalam penelitian ini menggunakan cara pengumpulan data meliputi studi pustaka, browsing internet, pengamatan langsung dan wawancara terbuka. Dalam mengamati perilaku dan karakter siswa yang fenomenal berupa karakter beretika melalui berpakaian, berpenampilan, bertutur kata baik di sekolah maupun di lingkungan masyarakat. Pengamatan selanjutnya untuk mengetahui wujud perubahan dalam pengaplikasian nilai-nilai karakter yang dimiliki oleh ragam hias sarung tenun sutera Mandar terhadap perilaku siswa yang diawali dari keteladanan. Hasil data yang terkumpul dengan sumber yang beragam sehingga terbukti keabsahannya, digunakan teknik triangulasi sumber (Sutopo, 2006: 93). Teknik trianggulasi sumber data tergambarkan pada gambar 1 berikut.

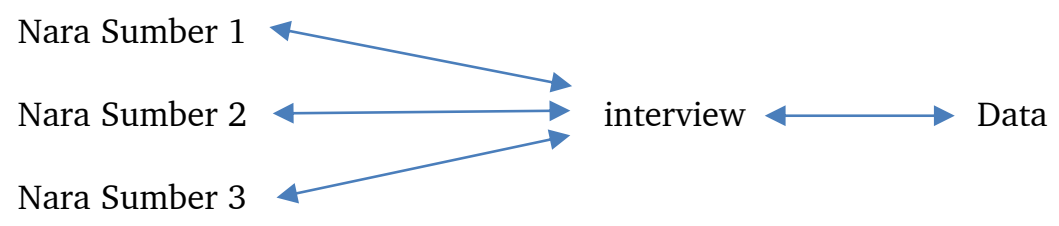

Gambar 1. Teknik trianggulasi sumber data. 
Beberapa narasumber hasil wawancara dicari kesamaan persepsinya untuk dijadikan sebagai kesimpulan sementara. Prosedur pelaksanaan pada analis data yang digunakan adalah mewawancarai beberapa nara sumber tokoh masyarakat, budayawan, tokoh pendidik untuk mengetahui pemaknaan atau simbol yang terdapat pada ragam hias sarung tenun sutera Mandar. Hasil dari wawancara dihubungkan dengan nilai-nilai karakter yang dimiliki pada ragam hias sarung tenun sutera mandar tersebut. Untuk menjawab rumusan masalah pertama kedua dilakukan interpretasi analisis dengan pendekatan emik untuk mencari kesamaannya. Dengan mengacuh kepada pendekatan antropologi melalui kajian emik, etik dengan memperhatikan nilai- nilai kultur budaya lokal Mandar. Selanjutnya untuk mengetahui transpormasi nilai-nilai karakter yang terdapat pada ragam hias sarung tenun sutera Mandar dengan pengamatan kepada siswa dalam berinteraksi mulai dari berpenampilan, berbicara, serta beraktivitas. Dalam menjawab rumusan masalah ketiga dilakukan pengamatan secara berkesinambungan dengan aktivitas keseharian tentang masalah sikap dan karakter digunakanlah pendekatan psikologis dan pembinaan karakter secara kontinutas terhadap peserta didik. Proses analisis data dilakukan lebih awal dengan pengumpulan data. Penelitian ini dikaji memalui metode analisis interaktif dengan memanfaatkan tiga variabel yaitu penyajian pengurangan data, dan hasil kesimpulan. Proses kerja dari analisis interaktif adalah tidak linear dan cenderung merupakan lingkaran kerja. Reduksi data merupakan komponen pertama dalam analisis proses selektif, penyederhanaan dan abstraksi data dari catatan lapangan. Reduksi data berlangsung secara terus menerus terhadap data-data yang didapatkan dari wawancara, studi pustaka, dan sepanjang penelitian dalam membuat validasi dari data lapangan. Deskripsi dalam bentuk tindakan yang lengkap disusun secara logis dan terstruktur. Pola alur interaksi analisis tersebut dapat digambarkan melalui skema gambar 2 berikut.

Pemaknaan Ragam
Hias Sarung Tenun
Sutera Mandar dari
Hasil Intervieu oleh
tokoh Masyarakat dan
budayawan

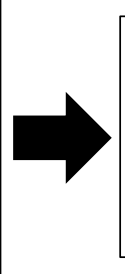

Transfer Nilai Nilai Makna Ragam Hias Pada Sarung Tenun Sutera Mandar Ke Siswa
Hasil dari transfer internalisasi karakter siswa

Gambar 2. Skema alur penelitian.

\section{Hasil dan Pembahasan Makna Ragam Hias Sarung Tenun Sutera Mandar}

Pemaknaan ragam hias sarung tenun sutera Mandar sebagai kearifan budaya lokal diawali dengan memahami makna simbol unsur ragam hias pola segi empat. Beberapa data dari nara sumber dan hasil riset tentang pemaknaan ragam hias sarung tenun sutera Mandar dapat diuraikan sebagai berikut. Menurut Saifuddin Bahrun, bentuk ragam hias sarung tenun sutera Mandar berbentuk pola segi empat. Makna pola segi empat yang nampak pada ragam hias sarung tenun sutera Mandar, tersusun secara terstruktur dengan beberapa garis tegak lurus keatas dangan pola garis lurus kesamping sehingga terbentuk motif kotak. Unsur garis kesamping atau horisontal tersebut memiliki arti kekuatan dan kedisiplinan tatanan kehidupan dalam masyarakat di Polewali Mandar yang menata secara jelas tentang komunikasi antara rakyat dan pemerintahan. Garis vertikal berkaitan dengan hubungan manusia dengan sang Pencipta. Masyarakat Mandar menyebutkan gambaran kotak tersebut dimaknai sebagai pagar untuk menghindari dari berbagai ancaman dan gangguan dari luar. Selain itu pagar juga dapat dimaknai sebagai hal pembeda antara mana yang halal dan haram. Sehingga dengan demikian pagar berfungsi sebagai penjaga dan pelindung harkat dan martabat diri bagi yang menggunakannya. (Bahrum, 2008: 3).

Lebih lanjut Majid (2003) menuturkan bahwa arti dan makna bentuk kotak tersebut dengan mengacuh kepada pola hidup kesederhanaan yang sesuai dengan apa adanya dan berusaha keras untuk menggapai harapan yang dicita -citakan secara halal. Pola ragam hias pada sarung tenun sutera Mandar dengan motif kotak berukuran kecil dan besar. Hal ini bermakna dalam melakukan suatu pekerjaan dimulai dari hal yang kecil atau sederhana sampai yang besar. Demikian halnya dengan pewarnaan yang memiliki keterkaitan simbol dan makna misalnya coklat, hitam, dan merah hati, mengidentikasikan perilaku yang tegas, konsisten dan bijaksana yang melambangkan sikap jujur sesuai dengan ajaran agama yang diyakininya 
serta melambangkan kehidupan sesuai dengan kenyataannya. Lebih lanjut dijelaskan bahwa selain arti dan makna warna pada ragam hias sarung tenun sutera Mandar yang diasosiasikan kepada karakter manusia, warna juga berkaitan dengan tanda warna alam misalanya merah identik dengan api, hitam dan coklat identik dengan warna tanah. (Majid, 2003: 19)

Pemaparan tersebut menggambarkan bahwa makna ragam hias pola kotak memiliki keterkaitan antara hubungan yang baik antara manusia dengan sesamanya dan hubungan manusia dengan Tuhannya. Dengan demikian makna simbol tersebut sebagai wujud esensi manusia dalam kaitanya sebagai mahluk sosial, mahluk religius dalam menata kehidupan yang harmonis sebagai mahluk berbudaya.

Darmawan Mas'ud, memperkuat pendapat tersebut yang menjelaskan bahwa, bentuk ragam hias segi empat (geometris), mulanya dikenal dengan hiasan jala bermakna filosofi kesederhanaan, dengan nama empat segi (sulapaq appeq). Empat segi merupakan budaya fundamental keempat suku yang ada di Sulawesi Selatan dan Barat dikenal dengan budaya siri dan lokko (malu/ yang tak ternilai harganya pada diri seseorang). Budaya malu tersebut terbingkai pada unsur ragam hias kotak yang di luarnya ada empat hal sifat dan perilaku manusia secara fundamental yang harus ada pada dirinya yaitu merasa malu jika tidak memiliki sifat adil (adele) konsisten (getteng) bersikap jujur (lempuh) dan berkata sesuai dengan kenyataan (tongeng).

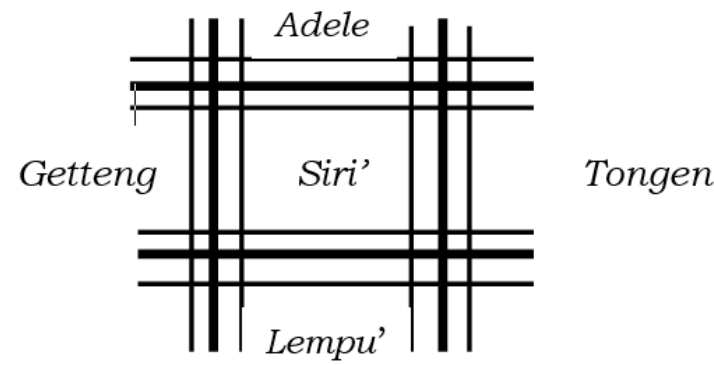

Gambar 3. Bentuk ragam hias segi empat (sulapaq appeq) dan makna yang terkandung pada sarung tenun sutera Mandar.

(wawancara dengan Darmawan Mas'ud)

Penggambaran pada gambar 3 di atas penekanannya terhadap etika moralitas manusia selaku mahluk berbudaya dengan perasaan malu jika melanggar norma-norma yang berlaku dalam masyarakat yang orientasinya kepada fitrah dengan adanya budaya siri yang ada pada diri manusia. Sehingga kebiasaan kebiasan yang tertata dan tertanam pada diri manusia telah yang tergambarkan dalam ragam hias sarung tenun sutera tersebut. Pernyataan di atas tentang pemaknaan ragam hias pada sarung tenun sutera Mandar menurut Anwar Sewang bentuk kotak segi empat tersebut dikaitkan pula pada pemahaman keempat sudat atau anasir tubuh dan bumi. Keempat anasir tubuh yaitu tana (tanah), uwai (air), anging (angin) dan afi (api). Tanah diasosiasikan sebagai macca (cerdas), air diasosiasikan sebagai perbutan yang jujur, angin diasosiasikan sebagi magetteng (konsisten tegas dalam perbuatan dan perlakuan) api diasosiasikan sebagai warani (pemberani).

\section{Transfer Nilai-Nilai Pendidikan Karakter yang Terdapat pada Ragam Hias Sarung Tenun Sutera Mandar}

Eksistensi bentuk ragam hias pola segi empat dalam tenunan sarung sutera Mandar mengandung arti dan nilai fundamental pada masyarakatnya. Bentuk ragam hias sarung tenun sutera Mandar dengan pola segi empat sebagai sifat dan identitas kepribadian masyarakat komunitasnya yang dijadikan acuan dan tuntunan dalam menata kehidupan bersama. Terkait dengan nilai menurut Herusatoto setiap karya dari manusia mempunyai suatu tujuan, dan di dalamnya terdapat suatu nilai. Misalnya nilai ekonomi, sosial budaya, keagamaan dan sebagainya. Berkreasi memiliki suatu tujuan arti dan maksud tertentu (Herusatoto, 1983: 10). Tidak terkecuali sebuah karya, walaupun memiliki bentuk yang tidak kompleks tetap memiliki arti dan nilai sebagai karya budaya. Sehingga dengan demikian berkreasi berarti menciptakan sebuah nilai.

Jika kita merujuk dari karya leluhur pada ragam hias sarung tenun sutera Mandar nilainilai pendidikan karakter yang terkandung di dalamnya diuraikan hasil kajian berbagai nara sumber sebagai berikut. Menurut Arifuddin Toppo garis tegak lurus ke atas mengandung makna sebagai perilaku religus dan nilai kejujuran. Garis tegak lurus melintang kesamping mengandung makna nilai karakter atau perilaku hubungan baik sesama manusia. Kaitanya dalam pendidikan karakter tentang nilai religus maka seorang guru harus senantiasa memberikan bimbingan kepada peserta didik dalam beribadah jika telah masuk waktu shalat di Musallah.

Nilai karakter kejujuran memperlihatkan suatu sikap positif dalam beraktivitas di sekolah. Kejujuran tersebut nampak ketika jujur mengatakan sesuatu baik atau buruknya. Hal ini dapat dijadikan panutan siswa dalam proses pembelajaran. (wawancara 31 Juli 2019). Masih terkait dengan pendidikan karakter Muhlis Hannam menuturkan sebagai garis tegak lurus 
pada ragam hias tenun sutera Mandar mencerminkan perilaku atau falsafah hidup masyarakat Mandar, terkait dengan hubungan yang baik dalam tatanan kehidupannya. Lebih lanjut penuturan Suaib Hannan senada yang diuraikan di atas yang berkaitan dengan ajaran agama dan moralitas pada diri manusia.

Hal ini mengindikasikan bahwa orang Mandar memiliki sifat perilaku menjunjung tinggi nilai-nilai kejujuran, kedisplinan, ketulusan budi pekerti yang teraplikasi pada ragam hias sarung tenun sutera Mandar yang tradisi (wawancara 30 Juli 2020). Pendapat ini seiring pula yang dijelaskan praktisi budaya Mandar Bodi \& Khalid (2009), bahwa arti dan makna simbol dalam ragam hias sarung tenun sutera Mandar tersebut sangat terkait dengan nilai etika perilaku orang Mandar yang senantiasa berupaya menjalani kehidupan yang apa adanya sesuai dengan kenyataannya. (Wawancara 4 Agustus 2020).

Kedua pendapat tersebut jelas memberikan suatu gambaran arti dan makna yang terkandung pada bentuk ragam hias itu mengandung nilai ajaran moralitas. Kaitanya dalam pengaplikasian nilai-nilai pendidikan budi pekerti pada peserta didik yang orientasinya dalam mewujudkan nilai nilai religus dan moralitas. Nilai religus dalam ketaatan beribadah menjalankan syariat agamanya dan menghargai keberagaman bagi penganut agama lain.

Aksi nyata nampak dalam kehidupan sosial masyarakatnya masih terpelihara dengan baik dalam kehidupan sehari-hari dengan perilaku kegotongroyongan saling bahu membahu kepedulian sosial, kebersamaan, yang mengutamakan daripada urusan pribadi. Pengaplikasian sikap dan perilaku tersebut dalam mendidik mental siswa sangat urgensi dalam memberikan pemahaman tentang hakikat eksistensi manusia sebagai mahluk sosial. Dalam pesan petuah leluhur Mandar memaparkan dengan sebutan ungkapan klasik bahwa Papiyai kedomu diparammu todi panjari kedodi tia disanga rupa tau artinya beretika dan beradab baiklah terhadap sesamamu, karena perilakulah dan karakter yang baik dapat mengidentifikasikan orang disebut manusia.

Berbagai pendapat lain dikemukakan diantaranya, H. Abdul Fatir selaku budayawan dan tokoh pendidik menjelaskan bahwa bentuk ragam hias kotak pada sarung tenun sutera Mandar terdapat suatu nilai kebersamaan dalam mewujudkan kekuatan. Sehingga terwujud hubungan yang harmonis terungkap dalam bahasa klasik sipakalebbi, sipakainge (saling memanusiakan, menghargai, dan mengingatkan) dan sirondo-rondoi (saling menyayangi). Pernyataan klasik tersebut merupakan pemaparan unsur nilai humanistik yang mengatur hubungan sosial warga masyarakat Polewali Mandar. Kaitanya dengan pendidikan karakter di sekolah kerjasama tersebut diwujudkan dalam kebersamaan mencapai misi dan visi sekolah sesuai dengan foksi masing masing (wawancara 25 Juli 2020). Pendapat ini dipertegas oleh tokoh masyakat Mandar $\mathrm{H}$. Ahmad Asdy bahwa makna dan arti yang terkandung pada ragam hias tenun Mandar itu dengan pola empat segi tersebut mengidentikasikan wujud kebersamaan dalam membagun kekuatan untuk meringankan beban pekerjaan dalam hubungan antara suami dan istri dalam pemenuhan kehidupan masyarakat di Mandar dikenal dengan istilah Siwaliparri (gotong royong). Pendapat ini dapat dipahami tentang perwujudan suatu nilai kerjasama dalam mencapai tujuan yang diinginkan sesuai dengan kemampuan yang dimiliki. Wujud kegotongroyongan untuk meringankan beban pekerjaan dalam kehidupan masyarakat Mandar termasuk guru dan siswa sebagai warga sekolah. Kaitannya dengan nilai-nilai pendidikan karakter pada siswa tersebut teraplikasi pada perwujudan sikap kerja keras, demokrasi, disiplin, dan tanggung jawab. Kerja sama dalam perwujudan karakter siswa orientasinya pada kegiatan diskusi dan kerja kelompok, menghargai pendapat teman, serta memilik kepedualian dalam menyelesaikan tugas bersama.

\section{Internalisasi Makna Ragam Hias Sarung Tenun Sutera Mandar terhadap Nilai-Nilai Karakter Bagi Peserta Didik}

Memahami beberapa pemaknaan nilai karakter yang terdapat dalam ragam hias sarung tenun sutera Mandar untuk dapat diinternalisasikan dalam pembinaan karakter dan mentalitas positif bagi peserta didik memerlukan suatu proses yang berkesinambungan. Abdul Fatir (wawancara 20 Agustus 2020). Lebih lanjut dijelaskan oleh Anwar Sewang bahwa internalisasi pemahaman makna ragam hias sarung tenun sutera Mandar tersebut. Harus pula ada tindak lanjutnya sebagai penghayatan dan perlakuan terutama bagi kaum pendidik seluruh warga sekolah tanpa kecuali dan tokoh masyarakat yang dijadikan panutan. Perlakuan dan tindakan bagi kaum pendidik dan orang tua merupakan jalan terbaik dalam pengaplikasian makna ragam hias sarung tenun sutera Mandar dalam kaitannya pendidikan karakter di sekolah. Termasuk merealisasikan nilai-nilai budaya siri (malu) (wawancara 16 
Agustus 2020). Dari berbagai pandangan para tokoh masyarakat dan tokoh pendidik dapat ditarik suatu kesimpulan bahwa. Pengaplikasian makna ragam hias tenun sutera Mandar kepada peserta didik di sekolah diawali dengan adanya kesadaran untuk berbuat dalam wujud secara ikhlas melakukan pembiasaan. Hal ini dilakukan secara kontunitas sehingga memberikan muatan positif yang menjadi kebiasaan yang pada akhirnya menjadi ciri khas dan melahirkan identitas dalam mewujudkan jati diri.

$$
\text { Sebagai seorang pendidik yang }
$$

bersentuhan langsung tentang situasi dan kondisi di sekolah pembinaan karakter yang berorientasi dengan jati diri yang telah diwariskan dari pendahulu maka seyogyanya ada pemahaman mendalam tentang pengintegrasian karakter yang terdapat pada konsep desain intruksional dan pelaksanaan kegiatan belajar mengajar serta asesmen pembelajaran. Pengaplikasian pada perencanaan pembelajaraan maka dengan sendirinya tercermin dari kemampuan guru dapat merumuskan pembelajaran tersebut yang diintegrasikan sikap dan perilaku karakter yang terintegrasikan pada makna ragam hias sarung tenun sutera Mandar. Mulai dari metode, strategi dan kegiatan pembelajaran seperti menanamkan sifat bekerja keras dan tidak mudah menyerah dalam mencari literatur, serta konsisten dalam berkarya, memiliki rasa ingin tahuan yang tinggi serta jujur dalam ulangan. Bentuk-bentuk pengaplikasian tersebut dapat dilakukan ketika berinteraksi antara guru dengan guru, guru dengan peserta didik serta peserta didik dengan sesamanya.

Internalisasi karakter siswa terlihat adanya perubahan perlahan secara nyata, namun masih ada yang perlu pembinaan peserta didik secara berkesinambungan. Perubahan sikap dan perilaku peserta didik diantaranya dari aspek religius, moralitas, humanistik dan kemandirian. Kegiatan religius nampak antusias siswa beribadah ketika masuk waktu shalat. Selain itu sebelum pembelajaran dimulai maka dengan sendirinya adanya pembiasaan siswa berdoa sesuai dengan agama dan kepercayaanya. Saling menghargai dan bertoleransi dari berbagai perbedaan baik etnis maupun agama.

Dari aspek moralitas dan humanistik perilaku siswa menampakkan keharmonisan dalam berinteraksi, bersatu bergotongroyong dalam mengerjakan tugas misalnya tugas kelompok dalam berdiskusi. Keharmonisan dan rasa kebersaman tersebut implementasinya dapat menghindari tawuran. Aspek moralitas menampakkan perubahan perilaku baik berupa ucapan maupun berpenampilan. Berpicara santun kepada guru, pegawai dan temantemannya. Dilihat dari aspek kemandirian dan kreativitas adanya hasil karya siswa misalnya pemanfaatan berbagai barang sisa atau sampah dalam berkarya seni rupa. Hal ini dapat pula membantu kepedulian dalam pelestarian lingkungan. Hasil karya tersebut dapat membekali siswa jika mereka telah kembali kemasyarakat.

\section{Simpulan dan Saran}

Pemaknaan ragam hias sarung tenun sutera Mandar sebagai kearifan budaya lokal dengan bentuk pola segi empat memiliki makna filosofi mendasar tentang budaya malu (siri) dan nilai mendasar bagi kehidupan sosial budaya masyarakatnya. Esensi makna simbolnya mewujudkan manusia sebagai mahluk berbudaya, mahluk sosial, dan mahluk religius. Budaya siri yang terbingkai empat mengandung makna ajaran kejujuran, konsisten, adil, dan berkata benar.

Nilai-nilai pendidikan karakter yang terdapat pada ragam hias sarung tenun sutera Mandar antara lain. Nilai religius tergambarkan dalam bentuk garis lurus vertikal yang bermakna sebagai hubungan manusia dengan Tuhannya yang mencerminkan insan yang beriman dan bertaqwa. Garis horizontal bermakna hubungan sosial yang terjalin dengan baik. Hubungan ini terbangun sifat kepribadian toleransi, bersahabat/ komunikatif. Nilai Kejujuran tergambarkan dari bentuk garis yang lurus dan tegas, disiplin/konsisten dan berkata benar.

Internalisasi makna simbolik ragam hias sarung tenun sutera Mandar terhadap nilai- nilai pendidikan karakter bagi peserta didik didasari budaya siri (malu). Sehingga terwujud perubahan kearah yang positif terhadap nilai karakter religus, moralitas, humanistik, dan nilai kemandirian. Internalisasi pemaknaan simbol dengan pemberian pemahaman makna kepada peserta didik tentang nilai-nilai luhur yang terkadung pada ragam hias sarung tenun sutera Mandar. Internalisasi nilai-nilai luhur karakterdimulai oleh pendidik, warga sekolah, sebagai wujud keteladanan selanjutnya terinternalisasi kepada siswa secara berkesinambungan. Perubahan tingkah laku nampak dari aspek berpenampilan secara santun dan ramah dan berbicara secara sopan.

Sebagai saran dalam hasil penelitian ini, peneliti dapat menjadikan rujukan untuk penelitian selanjutnya yang berkaitan dengan judul tulisan ini dengan tema yang berbeda. 


\section{Daftar Pustaka}

Asmani, Jamal Ma' mur. (2011). Buku Panduan Internalisasi Pendidikan Karakter di Sekolah. Yogyakarta: DIVA Press.

Bahrum Shaifuddin. (2008). Tenun Tradisonal Tenun Mandar Sulawesi Barat, Internet http blog Baruga Makassar, di Unduh 15 Januari 2018.

Bodi, M, \& Khalid, I. (2009). Tenun Sutera Mandar Sulawesi Barat. Surakarta: Zada Haniva

Dharsono, Sony Kartika. (2007). Seni Rupa Modern, Bandung: Rekayasa Sains.

Faisal, Arsitektur. (2008). Mandar Sulawesi Barat. Jakarta: Direktorat Jenderal Nilai Budaya dan Film Departemen Kebudayaan dan Pariwisata.

Guntur. (2008). Ornamen Sebuah Pengantar. Surakarta: P2AI STSI Press.

Herusatoto, Budiono. (1983). Simbolisme dalam Budaya Jawa. Yogyakarta: Hanindita.

Kartiwa, Suwati. (2007). Ragam Kain Tradi Indonesia Tenun Ikat. Jakarta: PT Gramedia Pustaka Utama.

Kasiyan. (2007). Lanskap Tradisi Praksis Kriya, dan Desain. Yogyakarta: BP ISI Yogyakarta

Kementerian Pendidikan Nasional. (2011). Pedoman Pelaksanaan Pendidikan Karakter. Jakarta: Puskurbuk.

Koentjaraningrat. (1984). Kebudayaan Mentalitas dan Pembangunan. Jakarta: PT Gramedia.

Majid, I. J. (2003). Budaya Tradisional Mandar Membuka Cakrawala Budaya Wanita Indonesia. Makalah dipresentasikan dalam Lokakarya Busana Nasional Wanita Indonesia di Ujung Pandang 19 Juli 2003.

Muchlis, M. (2016). Pendidikan karakter menjawab
Multidimensional, jet. v Jakarta: Bumi Aksara.

Sewang, Anwar. (2000). Sosialisasi Siri Pada Masyarakat Mandar Suatu Analisa Antropologi Tentang Sistem Nilai Budaya Mandar. Polewali Mandar: Yayasan Maha Putra.

Sutopo, H. B. (2006). Metodelogi Penelitian Kualitatif Dasar Teori dan Terapannya dalam Penelitian, Surakarta: UNS.

Yudha Triguna. (2000). Teori Tentang Simbol, Dempasar: Widya Dharma.

Zakia Darajat. (2009). Pembinaan Remaja, Jakarta: Bulan Bintang.

Toekio Soegeng. (2013). Mengenal Ragam Hias Indonesia. Surakarta: ISI Pres artikelaz.com/pengertian-budaya-lokal/ $31 \mathrm{Mei}$ 2016 diunduh 20 Januari 2018.

http://www.habibullahurl.com/2017/08/penge rtian-motif-dan-pola-ragam-hias.html diunduh 20 Januari 2018.

Nara Sumber

1. Abdul Fatir Budayawan (60 tahun) dan Tokoh Pendidikan Polewali Mandar.

2. Arifuddin Toppo (58 tahun) Kadis Pendidikan dan Kebudayaan Provinsi Sulawesi Barat Tokoh dan Tokoh Masyarakat Mandar.

3. Anwar Sewang (62 Tahun) Rektor IAI DDI Polman Tokoh Masyarakat Praktisi Pendidikan Kabupaten Polewali Mandar.

4. H. Ahmad Hasdi (75 Tahun) Tokoh Masyarakat dan Budayawan Mandar.

5. Muhlis Hannan (72 Tahun) Tokoh Masyarakat dan Pendidikan Kabupaten Polewali Mandar.

6. Darmawan Mas'ud (75 Tahun) Guru Besar dan Pakar Budaya Mandar. 